\title{
Biotransformation of dihydrocoumarin by Aspergillus niger ATCC 11394
}

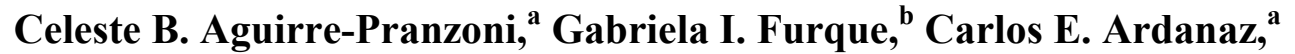 \\ Adriana Pacciaroni, ${ }^{b}$ Virginia Sosa, ${ }^{b}$ Carlos E. Tonn, ${ }^{a}$ and Marcela Kurina-Sanz ${ }^{\text {a }}$ \\ a Área de Química Orgánica-INTEQUI-CONICET, Facultad de Química, Bioquímica y \\ Farmacia, Universidad Nacional de San Luis, Chacabuco y Pedernera, D5700HHW, San Luis, \\ Argentina \\ ${ }^{b}$ Dpto. de Química Orgánica. IMBIV-CONICET, Facultad de Ciencias, Químicas. Universidad \\ Nacional de Córdoba, Ciudad Universitaria, X5000HUA, Córdoba, Argentina \\ E-mail: marcelakurina@gmail.com
}

\section{Dedicated to Professors Oscar S. Giordano, Manuel González Sierra, Julio C. Podestá and Rita Hoyos de Rossi}

\begin{abstract}
Aspergillus niger ATCC 11394 was used to catalyze the biotransformation of dihydrocoumarin using two experimental conditions: growing and resting cells. Six biotransformation products (27) were purified from the bio-reaction media and their structures elucidated by spectroscopic methods and mass spectrometry. The latter technique coupled to gas chromatography was used to analyze the time course of the biotransformations; from which results a metabolic pathway was proposed. The use of cytochrome P450 enzyme inhibitors, as well as working under poor oxygen conditions allowed us both to inquire about the type of enzymes involved in the process, and to design methods to prepare only metabolites that do not come from biological oxidations.
\end{abstract}

Keywords: Dihydrocoumarin, Aspergillus niger, metabolism

\section{Introduction}

Coumarins constitutes large group of phenolic compounds found in medicinal plants that share a common chemical structure of $2 H$-1-benzopyran-2-one. They are produced as plant secondary metabolites by the shikimic acid pathway. In families such as Umbelliferae, Apiaceae and Rutaceae coumarins accumulate in free form or as glycosides. In addition 2-hydroxycinnamic acid glycosides are enzymatically hydrolyzed and then lactonized into coumarins. ${ }^{1}$ Most of them have important biological effects including antioxidant, anti-inflammatory, anticoagulant, anti- 
allergic, antiviral, anticancer and enzyme inhibitor activities, ${ }^{2}$ although many are not suitable for therapeutic use because of their toxicity, carcinogenic and mutagenic activity. ${ }^{3}$

Particularly, dihydrocoumarin (DHC) is of great interest in the flavor industry since it is added to a wide variety of foods, and is used as a common fragrance in cosmetics. ${ }^{4}$ It has been isolated from Melilotus officinalis (sweet clover) and Dipteryx odorata Willd. (tonka beans). It is also obtained by bioconversion of coumarin by Saccharomyces cerevisiae into melilotic acid, which yielded DHC upon distillation during purification. ${ }^{5}$

The plant metabolomics is modified dramatically by the attacks of certain fungi due to induction of biosynthetic pathways involved in the defense. In parallel, filamentous fungi express several detoxification strategies, most of them with enzymes type cytochrome P450 (P450) involved. ${ }^{6}$ The reactions carried out by $\mathrm{P} 450$ in the presence of oxygen, NAD(P)H as cofactor and its corresponding electron transfer systems are diverse. These reactions involve the activation of $\mathrm{sp}^{3}$ hybridized carbon atoms, epoxidation of double bonds $\mathrm{C}=\mathrm{C}$ and aromatic hydroxylations. $\mathrm{P} 450$ also catalyze the oxidative coupling of phenol and dealkylation reactions such as dealkylation of alkyl coumarins. ${ }^{7}$ Aspergillus genus possesses the largest family of P450 so far known. For example A. oryzae and A. niger are reported to have 150 and 155 different P450 enzymes respectively. ${ }^{8}$ The interaction strategies between different types of organisms in a certain environment involved a variety of biological-chemical processes which, in the attempt to be elucidated, have contributed to the development of research areas such as stress metabolism and allelochemistry. In this context many of coumarin derivatives are involved in allelopathic processes, for instance our group has studied phytotoxic activity of some biotransformation metabolites. ${ }^{9}$

Biotransformations represent a suitable complement to the chemical transformation reactions in diversifying structures of bioactive compounds. The key advantage of these processes is that reactions are generally performed in chemo-, regio- and/or stereocontrol fashion. This issues allows them to compete and, in many cases, to overcome classical synthetic methodologies. The fact that most of the industrial chemical reactions involve the release of a large mass of waste products turns the biotransformations into a rational choice from the ecological point of view when planning a particular process.

In a previous work we have isolated DHC as the main product of the metabolism of coumarin by $A$. ochraceus and A. niger. ${ }^{10}$ The time course experiments using the later specie allow us to think about the possibility to prepare other coumarin metabolites by further biotransformations of DHC mediated by A. niger. This was based on the observation of two divergent pathways after the early reduction of the coumarin C3-C4 double bond to yield DHC: a) the lactone moiety opening and the further reduction of the carboxylic acid furnishing the primary alcohol 2-(3-hydroxypropyl)phenol and, b) the hydroxylation of the aromatic ring of dihydrocoumarin at a specific position to give 6-hydroxy-3,4-dihydrochromen-2-one. Here we report the study of DHC biotransformation using A. niger in both growing and resting cell systems in order to inquire into coumarins metabolic pathways and to find out methodologies to prepare a series of new metabolites to be further tested for bioactivity. 


\section{Results and Discussion}

Biotransformation of DHC (1) by growing and resting cell systems of A. niger ATCC 11394

A preliminary two step biotransformation procedure was carried out in growing and resting cell conditions as it is described in the experimental section. By analyzing the chromatograms (TLC, GC-FID and GC-MS) of the biotransformation extracts obtained from samples harvested at 24, 96, 144 and 168 hours after substrate inoculation it was evident the presence of a diversity of new compounds that were not present in blank essays.

Scaling up and structural elucidation of the biotransformation products: To determinate the chemical identity of the biotransformation products it was necessary to scale up the process in order to isolate and purified each metabolite. Taking into account the importance of not modifying any assay condition, particularly oxygenation parameters, the scaling up was in fact a resizing of the experiment, performed simply by increasing the number of culture batches in order to preserve all the biotransformation conditions. The GC profiles of the ethyl acetate extracts corresponding to the above mentioned harvesting times were compared. Since extracts from the 24 and 96 hours showed the presence of the same peaks they were joined after chromatographic evaluation. Likewise extracts from 144 and 168 hours. Then, both pools were purified in parallel by preparative $\mathrm{CC}$ and the six compounds were isolated and analyzed by ${ }^{1} \mathrm{H}$ and ${ }^{13} \mathrm{C}-\mathrm{NMR}$ and MS (Scheme 1).

From the former pool it was possible to isolate metabolites $\mathbf{2 , 3 , 4 , 5}$ and $\mathbf{6}$. The first one, which showed a $\mathrm{M}^{+}$at $\mathrm{m} / \mathrm{z}$ 166, resulted to be 3-(2-hydroxyphenyl)propanoic acid namely melilotic acid. ${ }^{11}$ The second (3), showed a molecular ion, fourteen units above $2, \mathrm{~m} / \mathrm{z} 180$, in agreement with what is expected for its methyl ester. This presumption was confirmed by the appearance of a singlet at $3.69 \mathrm{ppm}$ and a quartet at $52.30 \mathrm{ppm}$ in the ${ }^{1} \mathrm{H}$ and ${ }^{13} \mathrm{C}-\mathrm{NMR}$ spectra respectively.

It was particularly noticeable in the ${ }^{1} \mathrm{H}-\mathrm{NMR}$ spectrum of 4 the occurrence of a multiplet that integrates for two hydrogens at $1.92 \mathrm{ppm}(\mathrm{H}-2)$, together with the presence of two triplets at $3.01 \mathrm{ppm}(\mathrm{J}=7.2 \mathrm{~Hz})$ and $4.11 \mathrm{ppm}(\mathrm{J}=6.3 \mathrm{~Hz})$ corresponding to $\mathrm{H}-1$ and $\mathrm{H}-3$, respectively. No substitutions were obvious on the aromatic ring and there were no evidence of the existence of the lactone moiety since in the ${ }^{13} \mathrm{C}$-NMR spectrum one of the most noteworthy characteristics was the absence of a carbonyl peak (165-175 ppm). Taking into account that its $\mathrm{M}^{+}$. was $m / z 152$, and that the spectroscopic data was in agreement with previously reported data, ${ }^{12}$ the structure of 2-(3-hydroxypropyl)phenol is proposed. In addition, 5 resulted to be less polar than 4 and, presents a $\mathrm{M}^{+}$forty-two mass units higher than $4, \mathrm{~m} / \mathrm{z}$ 194. The ${ }^{1} \mathrm{H}$ NMR spectra showed a new singlet at $2.07 \mathrm{ppm}$ and two new carbons at the ${ }^{13} \mathrm{C}-\mathrm{NMR}$, one at 20.8 and the other at 171.4 ppm, all that is in agreement with a new acetyl moiety. The position of the acetate was assigned taking into account that the triplet corresponding to the hydrogens in C-1 (4.11 ppm) did not show any shift compared with the same signal in compound 4. According to Jackman \& Sternhell ${ }^{13}$ this signal should be shifted to lower fields (about $0.5 \mathrm{ppm}$ ) if the primary alcohol would have been acylated. In addition, as it is depicted in Scheme 2, the main peaks that 
appeared in MS spectrum could be attributed first to the loss of water and $\mathrm{C}_{2} \mathrm{H}_{4}$ simultaneusly to achieved a fragment of $\mathrm{m} / \mathrm{z}$ 148. It most likely suffers a rearrangement into its tropylic form which may be later converted in a dihydrofuran-2-one derivative. Then the rational loss of CO gives a high intensity fragment (43.8\%) at $\mathrm{m} / \mathrm{z} 120$ which further furnishes the tropilic ion as the logical base peak.

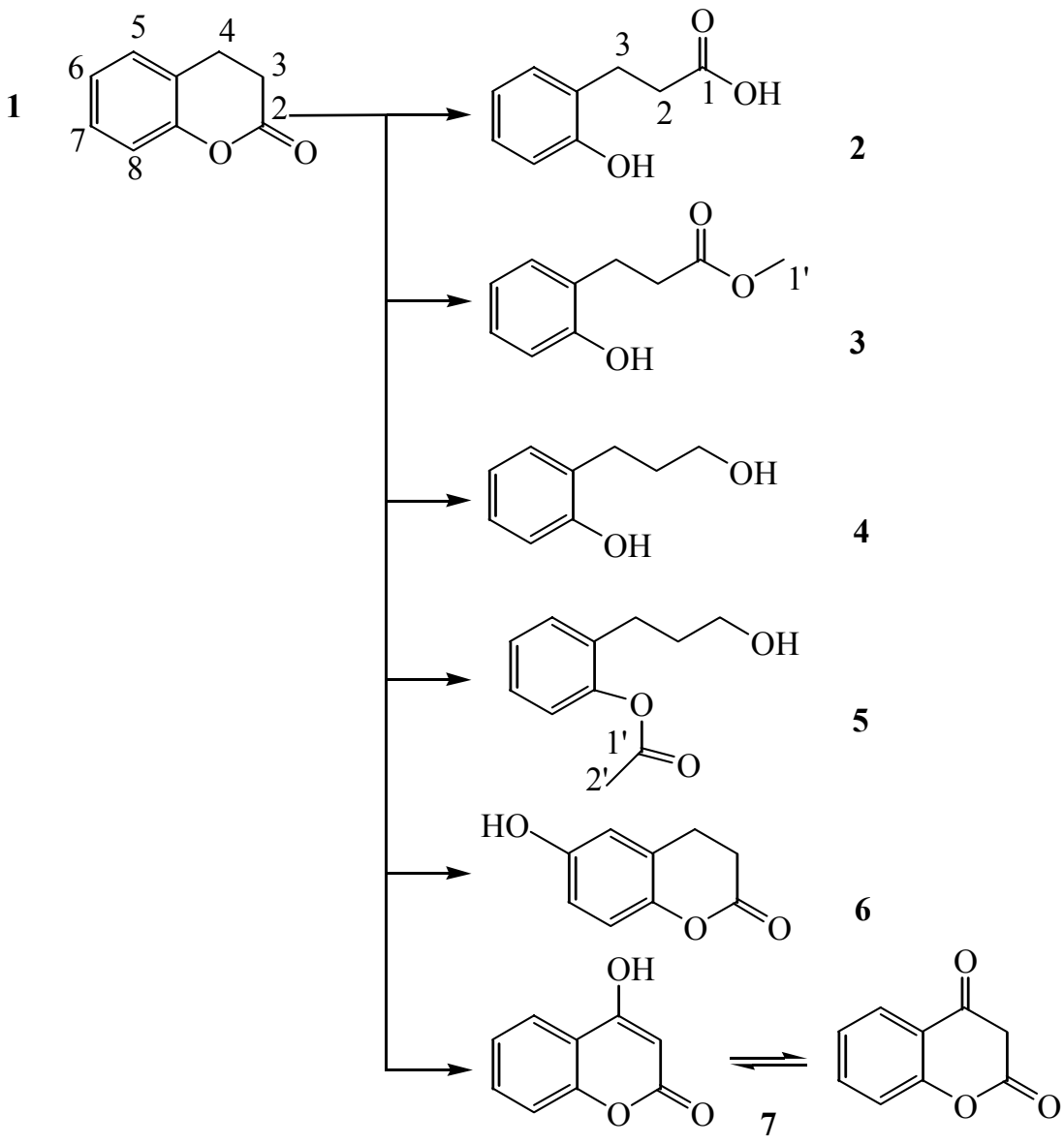

Scheme 1. Metabolites obtained from the biotransformation of DHC by A. niger ATCC 11394 growing cell system.

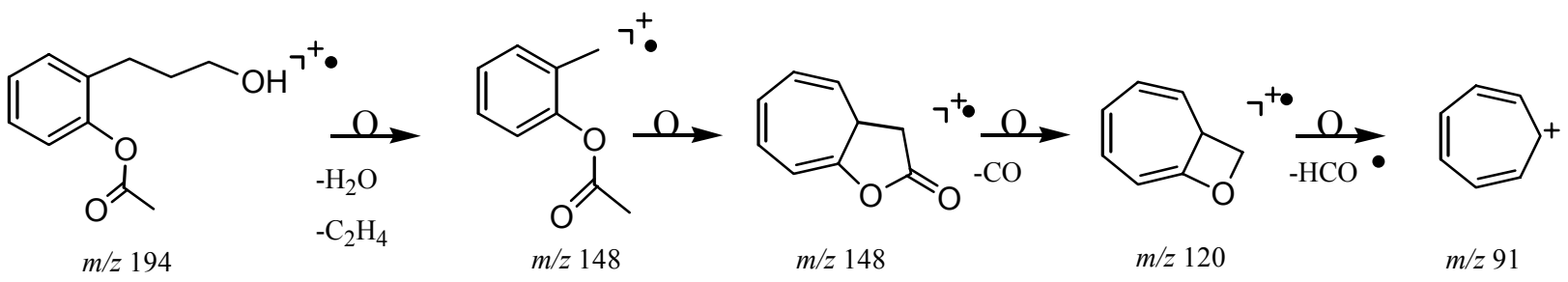

Scheme 2. MS fragmentation pattern of metabolite 5. 
On the other hand, none of the following fragments, which would be coherent if the acetyl group would be attached to the primary alcohol moiety, appeared in the MS spectrum: the result of the loss of fragments of 42 or $43 \mathrm{Da}$ (ketene or $\mathrm{C}_{2} \mathrm{H}_{3} \mathrm{O}$, respectively) to give the fragments at $m / z 152$ or 151 , or loss of fragments 59 or $60 \mathrm{Da}\left(\mathrm{C}_{2} \mathrm{H}_{3} \mathrm{O}_{2}\right.$ or acetic acid, respectively) to give the fragments at $m / z 135$ or 134 , as well as the loss of 87 Da by a benzylic fragmentation to furnish the fragment at $\mathrm{m} / \mathrm{z}$ 107. Consequently we assumed that the acetate is joined to the phenolic group and the structure of $\mathbf{5}$ is proposed as 2-(3-hydroxypropyl)phenyl acetate.

For metabolite 6, that showed a $\mathrm{M}^{+}$. determined by LRMS of $\mathrm{m} / \mathrm{z} 164$, it was easy to assume that it was a direct derivative of the enzymatic hydroxylation of $\mathbf{1}$ in the aromatic ring due to the presence of two signals (dd) between 2.70-3.00 ppm corresponding to H-3 and H-4. The assignment of the hydroxylation position on the aromatic ring could be solved by bidimensional homo and heteronuclear NMR spectroscopy. The signals at $6.67 \mathrm{ppm}, 6.71 \mathrm{ppm}$ and $6.92 \mathrm{ppm}$ were attributed to hydrogens 5, 7 and 8, respectively, due to a long distance correlation observed between $\mathrm{H}-5$ and $\mathrm{H}-3$ in the COSY-45 spectrum and H-3 and C-5 (114.4 ppm) in the HMBC.

From the second pool (extracts obtained from 144 and 168 hours bio-reaction samples) it was possible to recover the above described compounds 4, 5 and $\mathbf{6}$ together with metabolite 7, which was not isolated from the previous harvesting times although, it was detected by GC-MS at 96 hours of incubation. ${ }^{1} \mathrm{H}-\mathrm{NMR}$ spectrum of compound 7 , showed signals closely correlated with the expected for 3 or 4-hydroxycoumarin, because only one signal is observed as a singlet at $5.57 \mathrm{ppm}$, typical chemical shift for hydrogens on non-aromatic double bonds and no other signal is observed with the exception of the four aromatic hydrogens. It showed an $\mathrm{M}^{+}$. of $\mathrm{m} / \mathrm{z}$ 162 determined by LRMS. Substitution in C-4 was confirmed by analyzing the mass spectrum which shows that the fragment at $m / z 120$, corresponding to the loss of the ketene moiety, is the MS spectrum base peak. Furthermore, the intensity of the fragment at $\mathrm{m} / \mathrm{z} 121$ resulted to be two times higher than the expected intensity for the isotopic contribution to $m / z 120$, being that a clear evidence of the elimination of a $41 \mathrm{Da}$ fragment whose composition must necessarily be $\mathrm{HC}_{2} \mathrm{O}$. The loss of $\mathrm{CO}(\mathrm{M}-28)$ and $\mathrm{HCO}(\mathrm{M}-29)$ that would be characteristic of a substitution in C-3 were very small, even below the $2 \%$. The absence of fragments corresponding to M-17 ( $\mathrm{m} / \mathrm{z}$ $145)$ and $\mathrm{M}-18\left(\mathrm{~m} / \mathrm{z}\right.$ 144) attributable to the loss of $\mathrm{HO}$ and $\mathrm{H}_{2} \mathrm{O}$ respectively also match with the proposal that compound 7 correlates with 4-hydroxycoumarin which is in a tautomeric equilibrium strongly shifted to the keto form. Therefore we propose that compound $\mathbf{7}$ is in fact the tautomeric equilibrium between the enol and the keto forms of 4-hydroxy- $2 \mathrm{H}$-chromen-2one.

Time course experiments: The extracts belonging to each harvesting time were analyzed by GCMS, the above describe metabolites were detected and quantified in the different times and results collected from both, resting and growing cell experiments are presented as percentage of abundance in Table 1. 
Table 1. Time course biotransformation of DHC by A. niger ATCC 11394

\begin{tabular}{cclllllll}
\hline System & Time & \multicolumn{6}{c}{ Biotransformation products (Abundance \% ) } \\
\cline { 3 - 9 } & (hours) & 1 & 2 & 3 & 4 & 5 & 6 & 7 \\
\hline Growing cells & 0 & 100 & 0 & 0 & 0 & 0 & 0 & 0 \\
& 24 & 0 & 26.0 & 20.0 & 28.0 & 4.0 & 22.0 & 0 \\
& 96 & 0 & 15.0 & 8.4 & 38.0 & 4.6 & 24.0 & 10 \\
& 144 & 0 & 2.0 & 3.2 & 40.0 & 4.8 & 26.0 & 24.0 \\
Resting cells & 168 & 0 & 0.5 & 0.2 & 42.0 & 5.3 & 27.0 & 25.0 \\
& 0 & 100 & 0 & 0 & 0 & 0 & 0 & 0 \\
& 24 & 0 & 26.0 & 19.2 & 27.8 & 4.2 & 22.5 & 0.3 \\
Resting cells + & 96 & 0 & 14.3 & 8.6 & 38.2 & 4.5 & 24.2 & 10.2 \\
3 mM piperonyl butoxide & 144 & 0 & 1.7 & 3.4 & 39.8 & 4.7 & 26.1 & 24.3 \\
& 168 & 0 & 0.4 & 0.1 & 42.0 & 5.1 & 27.2 & 25.2 \\
& 0 & 100 & 0 & 0 & 0 & 0 & 0 & 0 \\
Static Resting cells & 24 & 0 & 66.0 & 0 & 30.0 & 4.0 & 0 & 0 \\
& 96 & 0 & 57.2 & 0 & 38.6 & 4.2 & 0 & 0 \\
& 144 & 0 & 55.2 & 0 & 40.0 & 4.8 & 0 & 0 \\
& 168 & 0 & 53.0 & 0 & 42.0 & 5 & 0 & 0 \\
& 0 & 100 & 0 & 0 & 0 & 0 & 0 & 0 \\
& 24 & 0 & 65.0 & 0 & 30.9 & 4.0 & 0.1 & 0 \\
& 96 & 0 & 57.0 & 0 & 38.6 & 4.2 & 0.2 & 0 \\
& 144 & 0 & 56.0 & 0 & 39.0 & 4.8 & 2.0 & 0 \\
& 168 & 0 & 50.0 & 0 & 40.0 & 5.0 & 5.0 & 0 \\
\hline
\end{tabular}

*Determined by GC-EM.

As it is depicted in the table, under the two basic bio-reaction conditions, growing and resting cells, metabolism profiles were almost coincident, just varying slightly in a few abundance percentages. Substrate was completely metabolized at the first harvesting time, 24 hours after its addition, when metabolites 2, 3, 4 and 5 were detected. The first one, melilotic acid (2), obviously came from the biocatalytic opening of the substrate lactone moiety since it was absent in blank assays without cells although $\mathrm{pH}$ values were the same. The further reduction of its carboxylic acid moiety, which could be rationalized by considering the reduction of 2 catalyzed by an alcoholdehydrogenase (ADH) type enzyme, yields the primary alcohol 4. Subsequent amendments of compounds $\mathbf{2}$ and $\mathbf{4}$ into their corresponding esterification products resulted in the presence of metabolites 3 and $\mathbf{5}$. At this incubation time a considerable amount of 6 (more than the $20 \%$ of abundance) appeared, likely due to monooxigenase activity, since it is the product of DHC hydroxylation in C- 6 . After 96 hours of incubation a new oxygenated metabolite came out, 7, but this time the enzymatic oxygen incorporation took place in the benzylic position $\mathrm{C} 4$. Our proposal to rationalize the appearance of $\mathbf{7}$ involves the regioselective 
hydroxylation in $\mathrm{C} 4$ which gives 4-hydroxydihydrocoumarin, a non isolated metabolite because it is rapidly re-oxidized into the ketone, which is in equilibrium with its enol form as it was above mentioned.

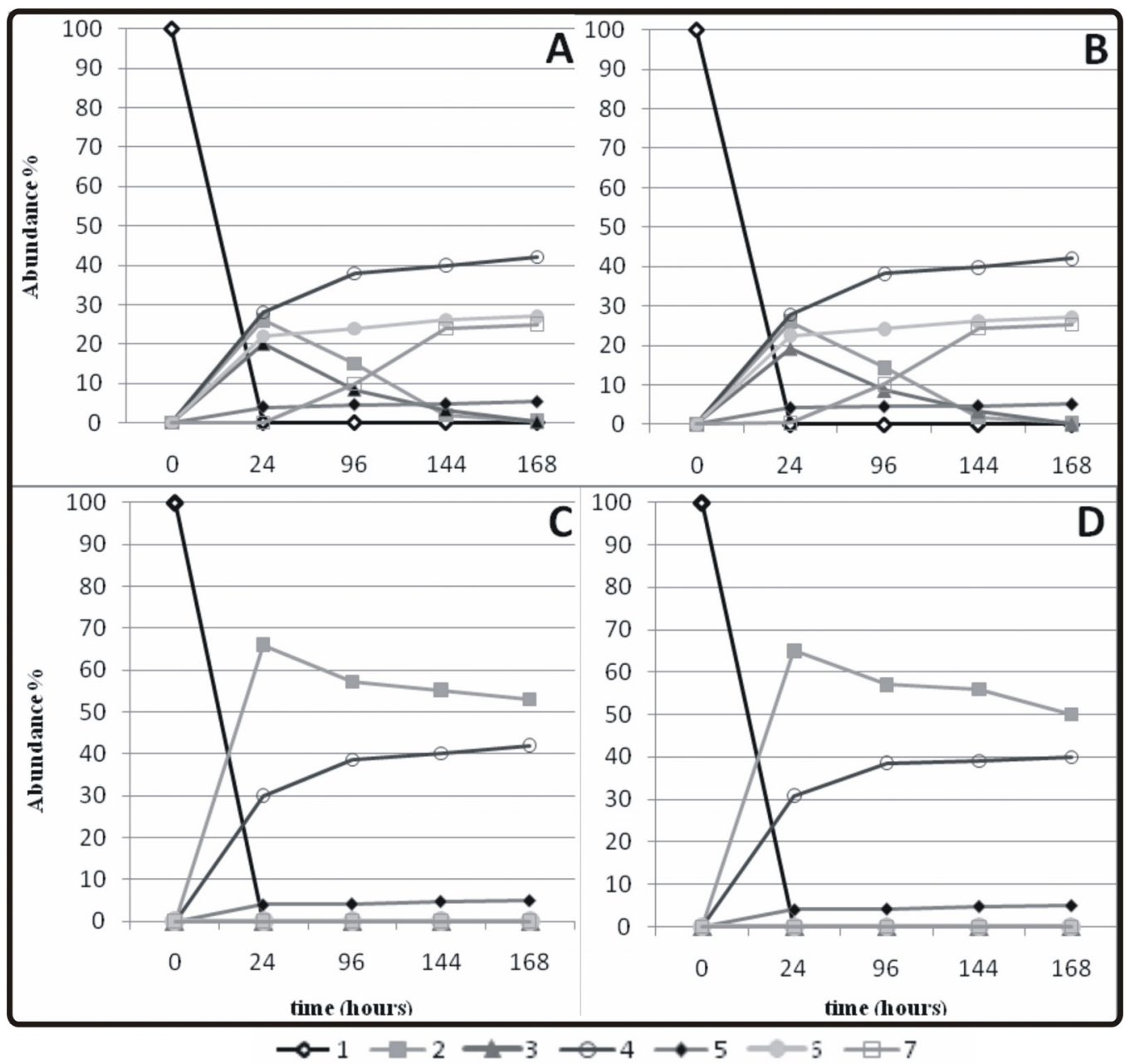

Figure 1. Time course biotransformation assays of DHC by A. niger ATCC 11394. A: Agitated growing cell system, B: Agitated resting cell system, C: Agitated resting cell system added with $3 \mathrm{mM}$ of PB, and D: Static resting cell system

At 144 hours, all the other metabolites were present although compound 4 clearly became into the main one, at the expense of the decrease of $\mathbf{2}$ and its methyl ester $\mathbf{3}$. The metabolic profiles of the two subsequent times (144 and 168 hours) were very similar. The alcohol 4 was consolidated as the main product of DHC metabolism (more than $40 \%$ of abundance) while the concentrations of both hydroxylation products ( 6 and 7) remained at the same levels, about $25 \%$ of abundance, in each case. The presence of the acetate $\mathbf{5}$ is maintained at stable levels throughout the process, which did not exceed the $5 \%$ of abundance. 
When piperonyl butoxide (PB), a potent P450 inhibitor ${ }^{14}$ and a non-specific esterase inhibitor in filamentous fungi, was added to resting cells systems no hydroxylated metabolites appeared (Table 1). The other compound that was not observed in this treatment was $\mathbf{3}$, the esterification product of melilotic acid. In addition, working at lower oxygen concentration, by using static resting cell systems, also prevented the accumulation of the oxygenated metabolites, in view of the fact that only very small amounts of compound $\mathbf{6}$ were observed in the final stages of the process. There were no differences by comparing with the treatments described above in relation to the quantity of the alcohol 4 and its acetate derivative 5, although it is noteworthy that the melilotic acid percentage increase in both cases. The results observed from both treatments give arguments to support that hydroxylations should be mediated by monooxigenase activity.

\section{Conclusions}

DHC biotransformation was achieved with A. niger ATCC 11394. By the analysis of the time course experiments it is sensible to propose a metabolic pathway for DHC which is illustrated in Scheme 3. It clearly shows the lactone moiety opening and its further reduction as key reactions of the reductive pathway, being the last reaction apparently mediated by pyridine-dependent $\mathrm{ADH}_{\mathrm{S}}$ type enzymes. The other path for DHC metabolism is likely to be mediated by monooxygenases type $\mathrm{P} 450$ since regioselective aromatic and benzylic hydroxylations took place. Also, addition of specific enzyme inhibitors to the bio-reaction media, as well as the experiment running under low aeration conditions, resulted in the absence or the drastically decrease of the quantities of the oxidized metabolites, respectively.<smiles>O=C1CCc2ccccc2O1</smiles>

1

b) oxidative pathway

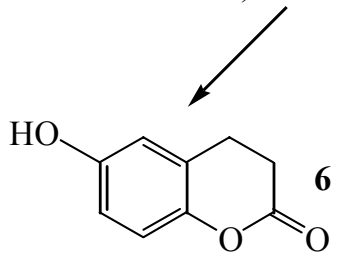

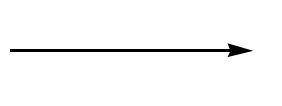

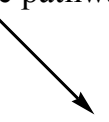<smiles>O=C1CC(O)c2ccccc2O1</smiles><smiles>O=C1CC(=O)C(=Cc2ccc3oc(=O)cc(O)c3c2)c2ccccc2O1</smiles><smiles>COC(=O)CCc1ccc(C)cc1O</smiles>

a) reductive pathway

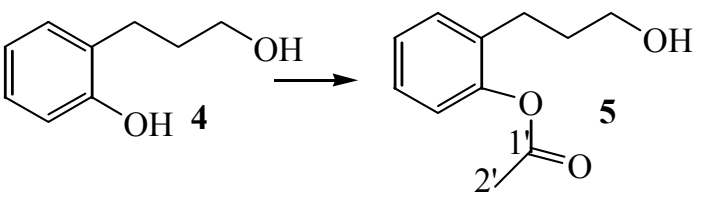

7

Scheme 3. Metabolism of DHC by A. niger ATCC 11394 in growing and resting cell systems 
Biocatalytic developments described here can serve as a starting point to optimize conditions so as to obtain coumarins derivatives through such environmentally friendly procedures since six biotransformation products (2-7) were purified from the bio-reaction media. Among them, the primary alcohol $\mathbf{4}$ and the hydroxylated compound $\mathbf{6}$ and $\mathbf{7}$ could be recovered in considerable amounts. Taking into account that resting cell systems are more easy-handle than growing cells, together with the fact that no significant differences in terms of metabolic profiles and amounts of biotransformation products were observed between both systems, we can conclude that resting cells represent the most practical way to prepare derivatives of DHC by biotransformation with $A$. niger. The presented results provide tools to handle bio-reaction methods and particularly to choose the proper incubation times and aeration conditions to obtain better yields of a particular metabolite.

\section{Experimental Section}

\section{Microorganisms}

Fungal strain was obtained from the American Type Culture Collection (A. niger ATCC 11394). Fungi were maintained on PDA-slants. Spore suspensions were obtained according to reported procedures and adjusted to $10^{7}$ spores with colony forming ability per milliliter in PBS with added Tween-20 $(5 \mu \mathrm{L} / \mathrm{mL})$ to inoculate the liquid media. ${ }^{15}$

\section{Chemicals}

DHC (1) and PB, (5-[2-(2-butoxyethoxy)ethoxymethyl]-6-propyl-1,3-benzodioxole) were purchased from Sigma-Aldrich Argentina; solvents were distilled prior to use.

\section{Analytical methods}

${ }^{1} \mathrm{H}-\mathrm{NMR}$ and ${ }^{13} \mathrm{C}$-NMR spectra were obtained on a Bruker AVANCE II 400 . BBI probe $(400$ $\mathrm{MHz})$ in $\mathrm{Cl}_{3} \mathrm{CD}$ and $\left(\mathrm{CD}_{3}\right)_{2} \mathrm{CO}$, $\left(400 \mathrm{MHz}\right.$ for ${ }^{1} \mathrm{H}$ and 100.25 to $\left.{ }^{13} \mathrm{C}\right)$. For structural elucidation the following 2D experiments also were used: COSY, HSQC, HMBC and DOSY. Chemical shifts in ppm are relative to TMS, coupling constants (J) are expressed in Hz. FT-IR spectra were obtained on a Nicolet Protegè 460 FTIR spectrophotometer. HR-MS data were recorded on Micromass VG AutoSpec (Manchester UK) at the Instituto Universitario de Bioorganica (Universidad de La Laguna, La Laguna 38206, Spain) at a resolution of 5000 (5\% valley definition), by $70 \mathrm{eV}$ electron ionization at an acceleration voltage of $8 \mathrm{kV}$. Melting points were measured in a Electrothermal IA9000 apparatus and are uncorrected. Analytical TLC was performed on Merck precoated silica gel $60 \mathrm{~F}_{254}$ plates. Solvent for TLC were n-hexane: EtOAc mixtures. Column chromatography was carried out on Merck silica gel 60 (230-400 mesh). GCFID analysis was performed in a Perkin-Elmer Clarus 500 instrument equipped with an Elite 5column $(30 \mathrm{~m}, 0.25 \mathrm{~mm} \mathrm{ID}, 0.25 \mu \mathrm{m} \mathrm{df}) \mathrm{T}_{1}=180^{\circ} \mathrm{C}\left(\Delta \mathrm{t}=10^{\circ} \mathrm{C} / \mathrm{min}\right), \mathrm{T}_{2}=320^{\circ} \mathrm{C}$ for $5 \mathrm{~min}$, $\left(\Delta \mathrm{t}=30^{\circ} \mathrm{C} / \mathrm{min}\right.$ ) $\mathrm{T}_{3}=350^{\circ} \mathrm{C}$, injector $\mathrm{T}=240^{\circ} \mathrm{C}$; carrier gas: $\mathrm{N}_{2} 35 \mathrm{~cm} / \mathrm{seg}$, splitless; FID T $=350^{\circ} \mathrm{C}$. 


\section{Biotransformation procedures}

Growing cells biotranformation. A two step process was conducted. Spore suspensions from the different Aspergillus strains were incubated in liquid Czapeck medium (sucrose $30 \mathrm{~g}$, yeast extract $5.0 \mathrm{~g}, \mathrm{KCl} 0.5 \mathrm{~g}, \mathrm{NaNO}_{3} 2.0 \mathrm{~g}, \mathrm{~K}_{2} \mathrm{HPO}_{4} 1.0 \mathrm{~g}, \mathrm{FeSO}_{4} 0.01 \mathrm{~g}, \mathrm{Mg}_{2} \mathrm{SO}_{4} .7 \mathrm{H}_{2} \mathrm{O} 0.5 \mathrm{~g}$, distilled water to $1000 \mathrm{ml}, \mathrm{pH} \mathrm{5}$ ) at $28^{\circ} \mathrm{C}$, on rotatory shaker at $180 \mathrm{rpm}$. Forty-eight-hour-old cultures $(5 \mathrm{ml})$ were subcultured in $125 \mathrm{ml}$ baffled Erlenmeyer flasks containing $30 \mathrm{ml}$ of fresh culture medium in a 10 pellets per batch relation. Substrate $(10 \mathrm{mg} / \mathrm{batch})$, dissolved in $100 \mu \mathrm{lof}$ dimethylsulfoxide (DMSO), was added to the cultures 24h later. Biotransformation progress was monitored by withdrawing a $30 \mathrm{ml}$ batch at $24 \mathrm{~h}, 96 \mathrm{~h}, 144 \mathrm{~h}$ and $168 \mathrm{~h}$, cultures were filtered and the broth filtrate extracted three times with EtOAc. Aliquots of the organic layers were analyzed by GC-FID $(1 \mu \mathrm{l})$ and TLC. Blank assays without substrates and without fungi were carried out in parallel. Experiments were performed by triplicate.

Resting cells biotransformation. Fungal pellets were harvested from 48 h-old cultures, washed with $0.1 \mathrm{M}$ pH 6 phosphate buffer and suspended in $30 \mathrm{ml}$ of fresh buffer. Incubation, substrate addition and work up procedures were carried out as described above for growing cell experiments.

In order to isolate de biotransformation products, several repetitions of the small-scale experiments were carried out. The crude extracts or the isolated metabolites were analyzed by GC-MS, ${ }^{1} \mathrm{H}-\mathrm{NMR}$ and ${ }^{13} \mathrm{C}-\mathrm{NMR}$.

3-(2-Hydroxyphenyl)propanoic acid (melilotic acid; 2): Amorphous solid, m.p.: 81-83 ${ }^{\circ} \mathrm{C}$ (from EtOAc). ${ }^{1} \mathrm{H}-\mathrm{NMR} \delta 2.50(\mathrm{t}, J=6.5 \mathrm{~Hz}, 2 \mathrm{H}), 2.77(\mathrm{t}, J=6.5 \mathrm{~Hz}, 2 \mathrm{H}), 6.69(\mathrm{t}, J=7.6 \mathrm{~Hz}$, $1 \mathrm{H}), 6.70(\mathrm{~d}, J=7.6 \mathrm{~Hz}, 1 \mathrm{H}), 6.98(\mathrm{dd}, J=7.6,1.3 \mathrm{~Hz}, 1 \mathrm{H}), 7.02(\mathrm{~d}, J=7.6 \mathrm{~Hz}, 1 \mathrm{H}) .{ }^{13} \mathrm{C}-\mathrm{NMR}$ $\left(\mathrm{CDCl}_{3}\right): 26.3,36.9,116.4,119.2,127.0,129.1,130.3,155.9,178.8 \mathrm{ppm}$. EI/MS: $\mathrm{m} / z$ (relative intensity): $\left[\mathrm{M}^{+}\right.$] 166 (0.9), 149 (3.6), 148 (15.3), 147 (2.2), 121 (5.1), 120 (51.1), 119 (18.4), 92 (11.6), 91 (100.0), 77 (17.5), 65 (11.2). IR vmáx $\left(\mathrm{cm}^{-1}\right) 3400(\mathrm{OH}), 3000$ br, $1725(\mathrm{C}=\mathrm{O}), 1450$ $\left(\mathrm{CH}_{2}\right), 1250,1170,1120,760$. HR-MS: $166.0635\left(\mathrm{C}_{9} \mathrm{H}_{10} \mathrm{O}_{3}{ }^{+}\right.$; calc. 166.0630). ${ }^{11,16}$

Methyl 3-(2-hydroxyphenyl)propanoate (3): White crystal, m.p. $39-41^{\circ} \mathrm{C}$ (from EtOAc). ${ }^{1} \mathrm{H}-$ NMR $\delta 2.73(\mathrm{t}, J=6.5 \mathrm{~Hz}, 2 \mathrm{H}), 2.91(\mathrm{t}, J=6.5 \mathrm{~Hz}, 2 \mathrm{H}), 3.69(\mathrm{~s}, 3 \mathrm{H}), 6.87(\mathrm{t}, J=7.8 \mathrm{~Hz}, 1 \mathrm{H})$, $6.88(\mathrm{~d}, J=7.8 \mathrm{~Hz}, 1 \mathrm{H}), 7.09(\mathrm{~d}, J=7.8 \mathrm{~Hz}, 1 \mathrm{H}), 7.12(\mathrm{t}, J=7.8 \mathrm{~Hz}, 1 \mathrm{H}) .{ }^{13} \mathrm{C}-\mathrm{NMR}\left(\mathrm{CDCl}_{3}\right)$ : 24.6, 35.0, 52.3, 117.2, 120.9, 127.3, 128.0, 130.6, 154.3, 176.1 ppm. GC-RT: $10.33 \mathrm{~min}$. EI/MS: $\mathrm{m} / \mathrm{z}$ (relative intensity): $\left[\mathrm{M}^{+}\right] 180$ (30.7), 148 (12.5), 120 (27.9), 119 (12.9), 91 (100). IR Vmáx (cm 1) $3400(\mathrm{OH}), 3100,3050,2850,2950,1745(\mathrm{C}=\mathrm{O}), 1450\left(\mathrm{CH}_{2}\right), 1250,1380,1245,756 . \mathrm{HR}-$ MS: $180.0782\left(\mathrm{C}_{10} \mathrm{H}_{12} \mathrm{O}_{3}{ }^{+}\right.$; calc. 180.0786).

2-(3-Hydroxypropyl)phenol (4): Brown oil. ${ }^{1} \mathrm{H}-\mathrm{NMR} \delta 1.92(\mathrm{~m}, J=6.7 \mathrm{~Hz}, 2 \mathrm{H}), 3.01$ (t, $J=7.2$ $\mathrm{Hz}, 2 \mathrm{H}), 4.11$ (t, $J=6.3 \mathrm{~Hz}, 2 \mathrm{H}$ ), 6.67 (bd, $J=8.0 \mathrm{~Hz}, 1 \mathrm{H}), 6.83$ (bt, $J=8.0 \mathrm{~Hz}, 1 \mathrm{H}), 7.04$ (bd, $J=$ $7.5 \mathrm{~Hz}, 1 \mathrm{H}), 7.10$ (bt, $J=7.5,1 \mathrm{H}) .{ }^{13} \mathrm{C}-\mathrm{NMR}\left(\mathrm{CDCl}_{3}\right): \delta 26.1,28.5,64.8,115.2,120.83,127.1$, 127.4, 130.3, 154.3 ppm. EI-MS: $m / z$ (relative intensity): $\left[\mathrm{M}^{+}\right] 152$ (11.5), 134 (69.8), 133 (34.1), 119 (48.2), 107 (22.0), 91 (100.00), 77 (60.3). IR vmáx (cm-1) 3400 (OH), 2926-2856, 2360-2340, 1635, 1653, 1558, 1541, 1458, 1055, 669. HR-MS: $152.0842\left(\mathrm{C}_{9} \mathrm{H}_{12} \mathrm{O}_{2}{ }^{+}\right.$; calc. 152.0837). 
2-(3-Hydroxypropyl)phenyl acetate (5): Colorless oil. ${ }^{1} \mathrm{H}-\mathrm{NMR} \delta 1.97(\mathrm{~m}, 2 \mathrm{H}), 2.07$ (s, 3H), $2.71(\mathrm{~m}, 2 \mathrm{H}), 4.11(\mathrm{t}, J=6.3 \mathrm{~Hz}, 2 \mathrm{H}),, 6.75(\mathrm{bd}, J=8.0 \mathrm{~Hz}, 1 \mathrm{H}), 7.04(\mathrm{bd}, J=7.7 \mathrm{~Hz}, 1 \mathrm{H}), 7.09$ (bt, $J=8.0 \mathrm{~Hz}, 1 \mathrm{H}), 7.10$ (bt, $J=7.7 \mathrm{~Hz}, 1 \mathrm{H}) .{ }^{13} \mathrm{C}-\mathrm{NMR}\left(\mathrm{CDCl}_{3}\right): \delta 20.1,26.1,28.5,63.79,115.2$, 120.6, 127.1, 127.5, 130.3, 153.7, $171.4 \mathrm{ppm}$. EI/MS: $m / z$ (relative intensity): $\left[\mathrm{M}^{+}\right] 194(5.5)$, 148 (18.8), 120 (43.8), $91(100.0)$. IR v $\operatorname{máx}\left(\mathrm{cm}^{-1}\right) 3370(\mathrm{OH}), 3100,3050,2920,1730(\mathrm{C}=\mathrm{O})$, $1450\left(\mathrm{CH}_{2}\right), 1383\left(\mathrm{CH}_{3}\right), 1240,754$. HR-MS: $194.0941\left(\mathrm{C}_{11} \mathrm{H}_{14} \mathrm{O}_{3}+\right.$; calc. 194.0943).

6-Hydroxy-3,4-dihydrochromen-2-one (6): Colorless oil. ${ }^{1} \mathrm{H}-\mathrm{NMR}: \delta 2.76$ (dd, $J=6.8,5.60 \mathrm{~Hz}$, 2H), 2.94 (dd, $J=6.8,5.6 \mathrm{~Hz}, 2 \mathrm{H}), 6.67$ (d, $J=3.2 \mathrm{~Hz}, 1 \mathrm{H}), 6.71$ (dd, $J=8.8,3.2 \mathrm{~Hz}, 1 \mathrm{H}), 6.93$ (d, $J=8.8 \mathrm{~Hz}, 1 \mathrm{H}) .{ }^{13} \mathrm{C}-\mathrm{NMR}: \delta 23.9,29.1,114.5,114.8,117.7,123.8,146.0,152.1,168.9$. EI/MS: $\mathrm{m} / \mathrm{z}$ (relative intensity): $\left[\mathrm{M}^{+}\right] 164$ (56.9), 136 (100.0), 135 (13.9), 122 (3.8), 121 (5.4), 107 (25.6), 94 (14.6), 91 (4.6), 79 (16.9), 77 (17.7), 66 (10.7), 65 (7.9). IR vmáx (cm-1) $3402(\mathrm{OH}), 2918(\mathrm{CH})$, 1736-1724 (C=O), $1466\left(\mathrm{CH}_{2}\right), 1198-1192(\mathrm{COC})$. HR-MS: $164.0467\left(\mathrm{C}_{9} \mathrm{H}_{8} \mathrm{O}_{3}{ }^{+}\right.$; calc. 164.0473). 4-Hydroxy-2H-chromen-2-one (7): White powder, m.p.:211-213 ${ }^{\circ} \mathrm{C}$ (from EtOAc). ${ }^{1} \mathrm{H}-\mathrm{NMR}$ : $\delta 5.57(\mathrm{~s}, 1 \mathrm{H}), 7.25(\mathrm{bd}, J=8.1 \mathrm{~Hz}, 1 \mathrm{H}), 7.29$ (dd, $J=6.6,1.0 \mathrm{~Hz}, 1 \mathrm{H}), 7.57$ (dd, $J=7.9,1.7 \mathrm{~Hz}$, $1 \mathrm{H}), 7.94(\mathrm{dd}, J=7.9,1.7 \mathrm{~Hz}, 1 \mathrm{H}) .{ }^{13} \mathrm{C}-\mathrm{NMR}: \delta 90.3,116.1,117.8,123.2,123.6,131.8,154.4$, 162.7, 167.9. EI/MS: $\mathrm{m} / \mathrm{z}$ (relative intensity): $\left[\mathrm{M}^{+}\right] 164$ (59.6), 134 (10.5), 120 (88.4), 92 (100). IR vmáx $\left(\mathrm{cm}^{-1}\right)$ 3125, 2941(CH), 1740-1750 (C=O), $1620(\mathrm{C}=\mathrm{O}), 1244$ (COC), 949, 833, 765, 748. HR-MS: $162.0321\left(\mathrm{C}_{9} \mathrm{H}_{6} \mathrm{O}_{3}{ }^{+}\right.$; calc. 162.0317). ${ }^{17}$

Time course biotransformation. The experiments were performed with growing and resting cells as described above, by collecting a $30 \mathrm{ml}$ batch assays at $24 \mathrm{~h}, 96 \mathrm{~h}, 144 \mathrm{~h}$ and $168 \mathrm{~h}$. Blank assays without substrates and without fungi were carried out in parallel. Aqueous media were extracted with EtOAc and evaporated under vacuum. Dried samples were resuspended in $500 \mu 1$ of EtOAc and analyzed by GC-MS. GC-MS analysis was performed with a GCQ-plus Finnigan Mat equipped with Restek 5-MS column 5\% diphenyl-95\% dimethylpolisiloxane (30 m, 0,25 $\mathrm{mm} \mathrm{ID,} 0,50 \mu \mathrm{m} \mathrm{df}) . \mathrm{T}_{1}=100^{\circ} \mathrm{C}$ for $3 \mathrm{~min},\left(\Delta \mathrm{t}=15^{\circ} \mathrm{C} / \mathrm{min}\right), \mathrm{T}_{2}=300^{\circ} \mathrm{C}$, injector $\mathrm{T}=250^{\circ} \mathrm{C}$; carrier gas: $\mathrm{He} 40 \mathrm{~cm} / \mathrm{seg}$. The instrument was run in EI mode at energy of $70 \mathrm{eV}$ (tune setting, trapoffset between -10 and -20 volts), ion source $183^{\circ} \mathrm{C}$, transfer line $250^{\circ} \mathrm{C}$, and mass range 50-400. Retention times (rt) under the above described conditions: 1: $9.25 \mathrm{~min}, 2: 11.01 \mathrm{~min}, 3: 10.33$ min, 4: $10.15 \mathrm{~min}$, 5: $11.35 \mathrm{~min}$, 6: $11.50 \mathrm{~min}$ and 7: $12.35 \mathrm{~min}$. Chemical identity was confirmed by co-injection with pure samples and MS spectra analysis.

Enzyme inhibition assay. Experiments were performed with resting cell systems in $30 \mathrm{ml}$ phosphate buffer ( $\mathrm{pH} \mathrm{6)}$ inoculated with fungal pellets harvested from $48 \mathrm{~h}$-old- A. niger cultures, with the addition of PB disolved in DMSO at a final concentration of $3 \mathrm{mM}$. Two hours later $10 \mathrm{mg} / \mathrm{batch}$ of substrate $\mathbf{1}$, were added. Incubations and sample withdraws were carried out under the above described conditions.

Static experiments: Experiments were also executed with resting cell systems but doubling the incubation buffer volume $(60 \mathrm{ml})$ and without the addition of inhibition agent. Incubation and sample withdraws were performed at the same conditions described but without agitation. 


\section{Acknowledgements}

This work was supported by grants from Universidad Nacional de San Luis 7301; PIP6228 CONICET and PICT 352 ANPCyT. C.A.P. and G.I.F. are doctoral CONICET fellows. C.E.T., V.S. and M.K.S are members of the Research Career of CONICET. The authors thank Lic. M. Ferrari for the technical assistance.

\section{References}

1. Dewick, P.M. Medicinal Natural Products. A Biosynthetic Approach. 2nd Edn.; Wiley: England, 2002; pp 142-146.

2. Riveiro, M.E.; De Kimpe, N.; Moglioni, A.; Vázquez, R.; Monczor, F.; Shayo, C.; Davio, C. Current Medicinal Chemistry 2010, 17, 1325.

3. Kostova I. Current Medicinal Chemistry-Anti-Cancer Agents 2005, 5, 29.

4. Adams, T. B.; Greer, D. B.; Doull, J.; Munro, I. C.; Newberne, P.; Portoghese, P. S.; Smith, R. L.;Wagner, B. M.; Weil, C. S.; Woods, L. A.; Ford, R. A. Food Chem. Toxicol. 1998, 36, 249.

5. Häser, K.; Henning-Wenk, H.; Schwab, W. J. Agric. Food Chem. 2006, 54, 6236.

6. Subramanian, V.; Yadav, J. S. Enzyme Microb. Technol. 2008, 43,141.

7. Urlacher, V. B.; Eiben, S. Trends Biotechnol. 2006, 24, 324.

8. Lah, L.; Krasevec, N.; Trontelj, P.; Komel, R. Fungal Genet. Biol. 2008, 45, 446.

9. Furque, G.I.; Pacciaroni, A.; Sosa, V XVII SINAQO-Simposio Nacional de Química Orgánica, Mendoza, Argentina, November 15-18, 2009: Abstract No PN-50

10. Aguirre-Pranzoni, C.; Orden, A.a.; Bisogno, F.R.; Ardanaz, C.E.; Tonn, C.E.; Kurina-Sanz, M. Fungal Biology in press, accepted December $19^{\text {th }}$. DOI:10.1016/j.funbio.2010.12.009.

11. Shukla, O.P. Appl.Environ. Microbiol. 1986, 51, 1332.

12. Kumari, G.N.K.; Ganesh, M.R.; Anitha, R.; Aravind, S. Zeitschrift für Naturforschung C. 2004, 59, 405.

13. Jackman, L.H.; Sternhell, S. Application of Nuclear Magnetic Resonance in Organic Chemistry. $2^{\text {nd }}$ Edn.Pergamon Press, 1969; pp. 164,179-180.

14. (a) Sato, A.; Watanabe, T.; Watanabe, Y.; Harazono, K.; Fukatsu, T. FEMS Microbiol. Lett. 2002, 213, 213. (b) Hiratsuka, N.; Wariishi, H.; Tanaka, H. Appl. Microbiol. Biotechnol. 2001, 57, 563.

15. Wright, L.; Scott, E.; Gorman, S. J. Antimicrob. Chemother. 1983, 12, 317.

16. Dictionary of Organic Compounds.5th Edn.; Chapman and Hall, 1982; pp 3322-3322.

17. Grasselli, J.G.; Ritchey, W.M., Editors. Atlas of Spectral data and Physical constants for Organic Compounds. 2nd Edn.; CRC Press, 1975; Vol III, pp 84-84. 